Short communication

\title{
Evidence of widespread ozone-induced visible injury on plants in Beijing, China
}

\author{
Zhaozhong Feng a, Jingsong Sun a, Wuxing Wan ${ }^{\text {b }}$, Enzhu Hu ${ }^{\text {a }}$, Vicent Calatayud ${ }^{\text {a, c, * }}$ \\ a State Key Laboratory of Urban and Regional Ecology, Research Center for Eco-Environmental Sciences, Chinese Academy of Sciences, Shuangqing Road 18, \\ Haidian District, Beijing 100085, China \\ ${ }^{\mathrm{b}}$ College of Life Science, Hebei Normal University, Shijiazhuang 050016, China \\ c Fundación CEAM, c/Charles R. Darwin 14, Parque Tecnológico, 46980 Paterna, Valencia, Spain
}

\section{A R T I C L E I N F O}

\section{Article history:}

Received 13 February 2014

Received in revised form

2 June 2014

Accepted 6 June 2014

Available online 29 June 2014

\section{Keywords:}

Air pollution

Ozone

Visible injury

Bioindicator plants

\begin{abstract}
A B S T R A C T
Despite the high ozone levels measured in China, and in Beijing in particular, reports of ozone-induced visible injury in vegetation are very scarce. Visible injury was investigated on July and August 2013 in the main parks, forest and agricultural areas of Beijing. Ozone injury was widespread in the area, being observed in 28 different species. Symptoms were more frequent in rural areas and mountains from northern Beijing, downwind from the city, and less frequent in city gardens. Among crops, injury to different types of beans (genera Phaseolus, Canavalia and Vigna) was common, and it was also observed in watermelon, grape vine, and in gourds. Native species such as ailanthus, several pines and ash species were also symptomatic. The black locust, the rose of Sharon and the Japanese morning glory were among the injured ornamental plants. Target species for broader bio-monitoring surveys in temperate China have been identified.
\end{abstract}

() 2014 Elsevier Ltd. All rights reserved.

\section{Introduction}

Ground-level ozone is increasing at a rate of approximately 0.5-2\% per year over the midlatitudes of the Northern Hemisphere due to fast industrialization and urbanization in the last three decades (IPCC, 2013). The fast economic development of China is producing serious air pollution problems, especially in Beijing. Ding et al. (2008) analysed aircraft ozone data obtained from the MOZAIC (Measurement of Ozone and Water Vapour by Airbus InService Aircraft) program for the 1995-2005 period and found that summertime ozone in the boundary layer near Beijing had increased by about $2 \%$ per year. The daily mean and hourly peak ozone concentrations at urban and exurban regions were $46 \mathrm{ppb}$ and $67 \mathrm{ppb}$, and 181 and $209 \mathrm{ppb}$, respectively, during May to September in 2010 (Wan et al., 2013). Such high ozone concentrations are expected to induce serious damage to plants.

Tropospheric ozone is known to interact with plants causing visible injury, impair photosynthesis, produce reductions in growth and yield, and alter plant interactions with pests and diseases (Krupa et al., 2000). In the context of 'global change', it may also

\footnotetext{
* Corresponding author.

E-mail address: calatayud_viclor@gva.es (V. Calatayud).
}

compromise stimulation of net primary production caused by elevated $\mathrm{CO}_{2}$ and reduce carbon sink capacity of ecosystems (Witting et al., 2009; Ainsworth et al., 2013). Ozone sensitivity is species-specific, with plants with higher Specific Leaf Area (the ratio of leaf area to dry mass) being in general more sensitive (Bussotti, 2008; Calatayud et al., 2011; Zhang et al., 2012). Plant responses to ozone also depend on their defence capacity (Di Baccio et al., 2008) and are affected by environmental conditions: optimal water supply, leaf temperature and light conditions promoting stomatal opening and gas exchange increase ozone uptake (LRTAP Convention, 2010; Ainsworth et al., 2013).

Among the different effects of ozone on vegetation, visible injury in leaves is considered a valuable tool for the assessment of ozone impacts in the field and to detect areas of high potential risk (Schaub et al., 2010). Although it is not as biologically significant as effects on growth and yield, it is indicative of ozone stress, and its presence and extent can be used as a surrogate of biological damage to the plants (Hayes et al., 2007). For this reason, the assessment of visible injury has been incorporated in European programs as the EU/ECE International Co-operative Programmes on Assessment and Monitoring of Air Pollution Effects on Forests (ICP Forests), and on Natural Vegetation and Crops (ICP Vegetation). Results from the European programmes have documented that visible injury on forest plants, crops and semi-natural vegetation occurs across 
Europe and in many species, although especially in Southern Europe where the ozone concentrations are higher (de Vries et al., 2003; Schaub and Calatayud, 2013; Hayes et al., 2007). In North America, visible injury has also been included in Forest Health monitoring programmes; it is frequently observed in several bioindicator plants of forested ecosystems of California (Campbell et al., 2007). Besides the results of these large-scale programmes, several other studies have focused on visible injury and on identification of suitable bioindicator species at a smaller scale in different parts of the world (e.g., Skelly et al., 1999; Fumagalli et al., 2001; Manning and Godzik, 2004; Sanz et al., 2001; Bergweiler et al., 2008; Coulston et al., 2003). However, despite the important pollution problems of China, reports of visible injury to vegetation are surprisingly low (Wan et al., 2013). This is partly due to the fact that recognition of ozone injury is complex and requires training (Bussotti et al., 2003). The main objective of present paper is to enlarge the knowledge of ambient ozone impacts on vegetation in Beijing by surveying foliar visible injury on different types of plants. This information is relevant to China, an economically emergent country which is importantly contributing to the new global scenario of air pollution and climate change.

\section{Methods}

In Beijing area, several field surveys were conducted during July and August 2013, by walking the main parks, forest and agricultural areas (Fig. 1). The end of the summer is the most appropriate time for conducting surveys on native vegetation as the cumulative effects of ozone during the growing season may not appear until that time (Skelly et al., 1987; Schaub et al., 2010).

Ozone visible injury was identified in the plant following the procedures for ozone symptom diagnosis of the ICP-Forest Manual (Schaub et al., 2010). In broadleaf species, symptoms are typically expressed as tiny purple, yellow or black spots (described as stipple) or sometimes as a general even discolouration, reddening or bronzing; flecking is characterized by small, discrete areas of dead tissue and may be more irregular in shape. In conifers, ozone effects are typically a diffuse chlorotic mottling affecting the older whorls of needles (Sanz et al., 2001; Vollenweider et al., 2013). Photos of ozone symptoms, preferably confirmed experimentally, have been used as a reference (Table 1 ). Selected leaf samples were examined by microscopy (data not shown) in order to rule out mimicking symptoms caused by other biotic or abiotic factors (Vollenweider et al., 2003). Skills for correct ozone injury identification of the corresponding author have been improved through regular participation in the ozone visible injury intercalibration courses organized by the ICP-Forest in Europe since 2000 (Bussotti et al., 2003).

\section{Results and discussion}

Ozone levels in Beijing area were high enough to induce foliar symptoms in 28 different species (Table 1). Areas with high impacts have been identified especially in the north of Beijing, downwind from the city: in Mang Mountains, the agricultural area close to Changping, and in the Olympic Forest Park (Fig. 1). Inside the city, ozone symptoms were less frequent, which is consistent with the local scavenge of ozone due to the ' $\mathrm{NO}_{\mathrm{x}}$ titration effect' typical of a polluted urban environment (Royal Society, 2008). Furthermore, in those sites assessed in July and in August, symptoms were more abundant in August, confirming the cumulative effect of ozone exposure (Fig. 2). In July, symptoms were observed only in Ailanthus (sites 1 and 6), in the Chinese long and common beans (site 2), in the Japanese morning glory (sites 1 and 6), and in the black locust, North China red elder and peach f. duplex (site 3).

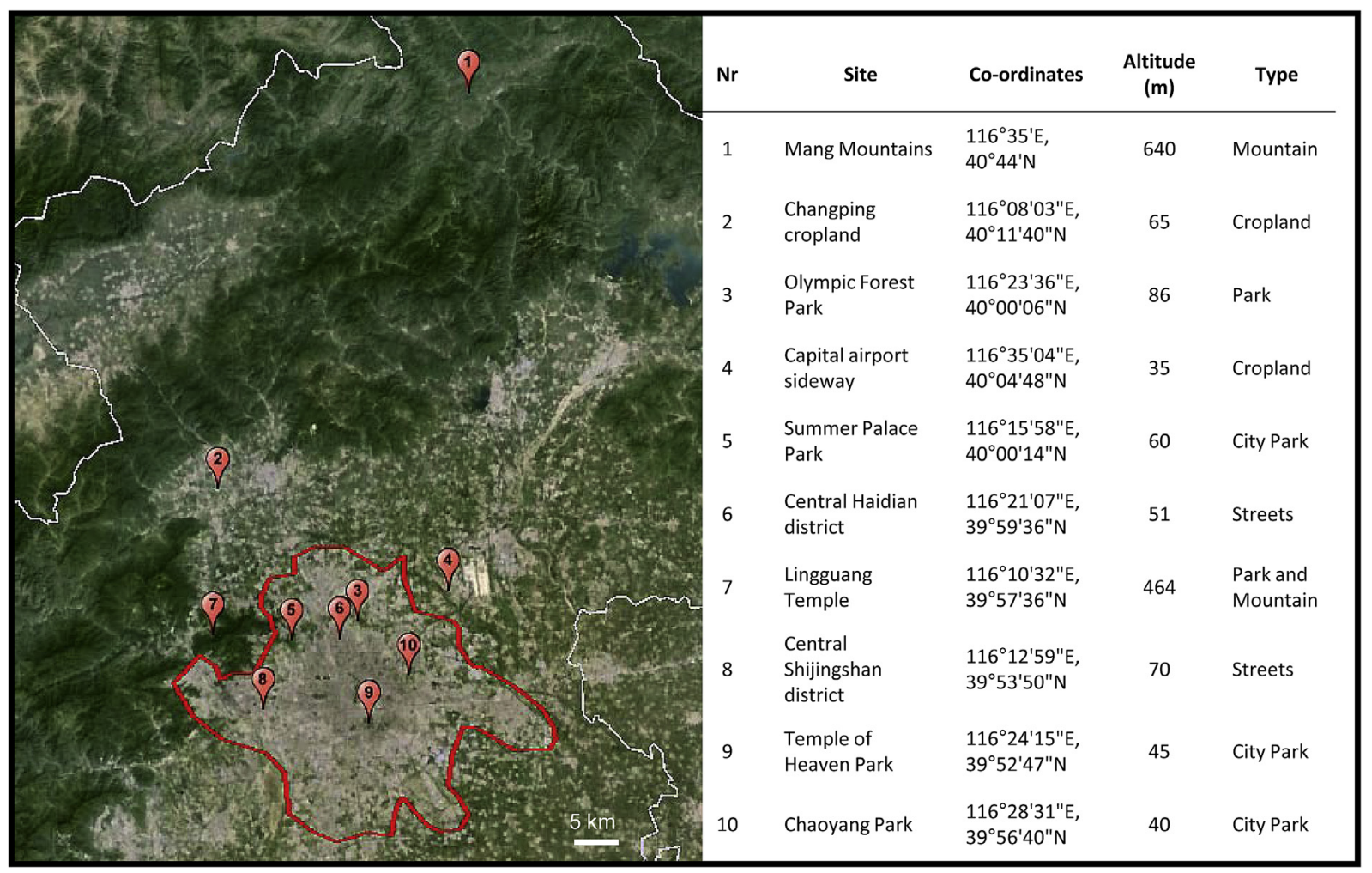

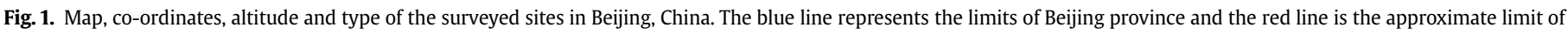
the urban area. Map: () Google, Mapabc.com. (For interpretation of the references to colour in this figure legend, the reader is referred to the web version of this article.) 
Table 1

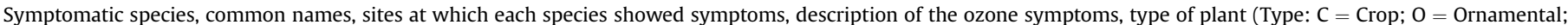
$\mathrm{N}=$ Native plant) and reference bibliography.

\begin{tabular}{|c|c|c|c|c|c|c|}
\hline Scientific name & Common name & $\begin{array}{l}\text { Sites with } \\
\text { symptoms }\end{array}$ & Symptom description & Type & $\begin{array}{l}\text { Reference photos under } \\
\text { controlled conditions }\end{array}$ & $\begin{array}{l}\text { Reference photos from } \\
\text { the field }\end{array}$ \\
\hline $\begin{array}{r}\text { Abelmoschus } \\
\text { esculentus }\end{array}$ & Okra plant & 2 & $\begin{array}{l}\text { Fine light brown and purple interveinal } \\
\text { stippling on the adaxial side of older leaves }\end{array}$ & $\mathrm{C}$ & Bulbovas et al., 2008 & This paper \\
\hline Abutilon theophrasti & $\begin{array}{l}\text { Velvetleaf, China } \\
\text { jute, Buttonweed }\end{array}$ & 2 & $\begin{array}{l}\text { Fine yellow to light brown stippling between } \\
\text { main and secondary veins, which remain green. }\end{array}$ & $\mathrm{C}$ & & This paper \\
\hline Ailanthus altissima & $\begin{array}{l}\text { Tree of } \\
\text { heaven, Ailanthus }\end{array}$ & $1,6,7,10$ & $\begin{array}{l}\text { Fine light-brown stippling on the upper surface } \\
\text { of the leaf. Stippling more abundant in older } \\
\text { leaves and leaflets. }\end{array}$ & $\mathrm{N}, \mathrm{O}$ & $\begin{array}{l}\text { Sanz et al., 2001; Sanz } \\
\text { and Calatayud, 2013; } \\
\text { Feng et al. } \\
\text { (unpublished)* }\end{array}$ & $\begin{array}{l}\text { Innes et al., 2001; Sanz } \\
\text { et al., 2001; Gravano } \\
\text { et al., } 2003\end{array}$ \\
\hline $\begin{array}{l}\text { Ampelopsis } \\
\text { humulifolia }\end{array}$ & - & 1 & $\begin{array}{l}\text { Very fine brown to purple-brown stippling } \\
\text { covering interveinal areas of the leaves }\end{array}$ & $\mathrm{N}$ & & Wan et al., 2013 \\
\hline Arachis hypogaea & Peanut & 7 & $\begin{array}{l}\text { Very fine light brown interveinal stippling, } \\
\text { finally also with dark purple stippling. }\end{array}$ & $\mathrm{C}$ & & This paper \\
\hline Benincasa pruriens & Winter gourd & 7 & $\begin{array}{l}\text { Fine light brown diffuse stippling between main } \\
\text { and secondary veins, which remain green. }\end{array}$ & $\mathrm{C}$ & & This paper \\
\hline $\begin{array}{r}\text { Broussonetia } \\
\text { paryrifera }\end{array}$ & Paper mulberry & 1,3 & Very fine interveinal light-brown stippling & $\mathrm{N}, \mathrm{O}$ & & Wan et al., 2013 \\
\hline Canavalia gladiata & Sword bean & $1,2,4,7,8$ & $\begin{array}{l}\text { Distinctive purple-brown or dark purple } \\
\text { stippling that can cover a large portion of the } \\
\text { interveinal areas of leaves. Sometimes with } \\
\text { associated chlorosis. }\end{array}$ & $\mathrm{C}$ & & This paper \\
\hline Citrullus lanatus & Watermelon & 2 & $\begin{array}{l}\text { Dark brown stippling on interveinal parts of } \\
\text { older leaves. Stippling evolves to form very } \\
\text { distinctive brown necrotic areas, sometimes } \\
\text { with associated white flecking. Chlorosis is } \\
\text { frequently observed together with stippling. }\end{array}$ & $\mathrm{C}$ & $\begin{array}{l}\text { Gimeno et al., 1989; } \\
\text { Sanz and Calvo, } 2013\end{array}$ & Sanz and Calvo, 2013 \\
\hline $\begin{array}{l}\text { Cotinus coggygria } \\
\text { var. pubescens }\end{array}$ & $\begin{array}{l}\text { Eurasian } \\
\text { smoketree, Smoke } \\
\text { bush }\end{array}$ & 1 & $\begin{array}{l}\text { Diffuse, very fine purple-brown colouration of } \\
\text { interveinal areas }\end{array}$ & $\mathrm{N}, \mathrm{O}$ & & Wan et al., 2013 \\
\hline Fraxinus chinensis & Chinese ash & 3 & $\begin{array}{l}\text { Fine light-brown stippling on interveinal parts } \\
\text { of the upper surface of older leaves. }\end{array}$ & $\mathrm{N}, \mathrm{O}$ & $\begin{array}{l}\text { Feng et al. } \\
\text { (unpublished)a , Other } \\
\text { Fraxinus species: } \\
\text { Paoletti et al., 2009b; } \\
\text { Sanz and Calatayud, } \\
2013\end{array}$ & $\begin{array}{l}\text { Other Fraxinus species: } \\
\text { Skelly et al., 1987; Innes } \\
\text { et al., 2001; Sanz et al., } \\
2001\end{array}$ \\
\hline $\begin{array}{l}\text { Fraxinus } \\
\quad \text { rhynchophylla }\end{array}$ & Korean ash & 3,10 & $\begin{array}{l}\text { Fine light-brown stippling on interveinal parts } \\
\text { of the upper surface of older leaves. }\end{array}$ & $\mathrm{N}, \mathrm{O}$ & $\begin{array}{l}\text { Other Fraxinus species: } \\
\text { Paoletti et al., 2009b; } \\
\text { Sanz and Calatayud, } \\
2013\end{array}$ & $\begin{array}{l}\text { Other Fraxinus species: } \\
\text { Skelly et al., 1987; Innes } \\
\text { et al., 2001; Sanz et al., } \\
2001\end{array}$ \\
\hline Hibiscus syriacus & Rose of Sharon & 2,3 & $\begin{array}{l}\text { Fine light-brown stippling on interveinal parts } \\
\text { of the upper surface of older leaves. In very } \\
\text { affected leaves, stippling becoming brown. } \\
\text { Chlorosis and increased leaf senescence. }\end{array}$ & $\mathrm{N}, \mathrm{O}$ & Paoletti et al., 2009a & $\begin{array}{l}\text { Sanz et al., 2001; } \\
\text { Paoletti et al., 2009a }\end{array}$ \\
\hline Humulus scandens & Hop & $1,2,3$ & Very fine light-brown interveinal stippling & $\mathrm{C}$ & & $\begin{array}{l}\text { Other Humulus species: } \\
\text { Manning and Godzik, } \\
2004\end{array}$ \\
\hline Ipomaea nil & $\begin{array}{l}\text { Japanese morning } \\
\text { glory }\end{array}$ & $1,6,8$ & Pale yellow or purpish interveinal stippling & $\mathrm{O}$ & Ferreira et al., 2012 & Ferreira et al., 2012 \\
\hline $\begin{array}{l}\text { Koelreuteria } \\
\quad \text { paniculata }\end{array}$ & $\begin{array}{l}\text { Goldenrain tree, } \\
\text { China tree }\end{array}$ & 1 & $\begin{array}{l}\text { Interveinal chlorosis and purple brown } \\
\text { stippling, especially in older leaves }\end{array}$ & $\mathrm{N}, \mathrm{O}$ & $\begin{array}{l}\text { Feng et al. } \\
\text { (unpublished) }\end{array}$ & Wan et al., 2013 \\
\hline Luffa cylindrica & Courgette & 1,2 & $\begin{array}{l}\text { Fine yellow to light brown stippling between } \\
\text { main and secondary veins, which remain green. }\end{array}$ & $\mathrm{C}$ & & $\begin{array}{l}\text { Velissariou (in Hayes } \\
\text { et al., 2007, pg. 20) }\end{array}$ \\
\hline $\begin{array}{l}\text { Malvaviscus } \\
\text { arboreus var. } \\
\text { penduliflorus }\end{array}$ & Wax mallow & 1 & $\begin{array}{l}\text { Fine brown interveinal stippling affecting older } \\
\text { leaves. Younger leaves are not affected and the } \\
\text { injury progress towards the base of the plant } \\
\text { where leaves are older. }\end{array}$ & $\mathrm{O}$ & & This paper \\
\hline $\begin{array}{r}\text { Parthenocissus } \\
\text { tricuspidata }\end{array}$ & Japanese creeper & 1 & Dark red stippling on the upper leaf surface & $\mathrm{N}, \mathrm{O}$ & & $\begin{array}{l}\text { Other Parthenocissus } \\
\text { species: Innes et al., } \\
\text { 2001; Sanz et al., } 2001\end{array}$ \\
\hline Phaseolus vulgaris & Common bean & 2,4 & $\begin{array}{l}\text { Distinctive purple-brown or dark purple } \\
\text { stippling that can cover a large portion of the } \\
\text { interveinal areas of leaves. Sometimes with } \\
\text { associated chlorosis. Severely affected leaves } \\
\text { finally becoming dry. }\end{array}$ & $\mathrm{C}$ & Sanz and Calvo, 2013 & Sanz and Calvo, 2013 \\
\hline Pinus bungeana & Lacebark pine & 3 & $\begin{array}{l}\text { Chlorotic mottling and accelerated senescence } \\
\text { affecting older leaves. Current year needles are } \\
\text { not affected }\end{array}$ & $\mathrm{N}, \mathrm{O}$ & $\begin{array}{l}\text { Other Pine species: } \\
\text { Sanz and Calatayud, } \\
2013\end{array}$ & $\begin{array}{l}\text { Other Pine species: } \\
\text { Sanz and Calatayud, } \\
2013\end{array}$ \\
\hline Pinus radiata & Radiata pine & 10 & $\begin{array}{l}\text { Chlorotic mottling and accelerated senescence } \\
\text { affecting older leaves. Current year needles are } \\
\text { not affected }\end{array}$ & $\mathrm{O}$ & & $\begin{array}{l}\text { Sanz and Calatayud, } \\
2013\end{array}$ \\
\hline $\begin{array}{l}\text { Prunus persica } f \text {. } \\
\quad \text { duplex }\end{array}$ & Peach f. duplex & 3 & $\begin{array}{l}\text { Dark purple stippling, usually more intense } \\
\text { towards the leaf margins }\end{array}$ & $\mathrm{C}$ & & $\begin{array}{l}\text { Other Prunus species: } \\
\text { Innes et al., } 2001\end{array}$ \\
\hline
\end{tabular}


Table 1 (continued)

\begin{tabular}{|c|c|c|c|c|c|c|}
\hline Scientific name & Common name & $\begin{array}{l}\text { Sites with } \\
\text { symptoms }\end{array}$ & Symptom description & Type & $\begin{array}{l}\text { Reference photos under } \\
\text { controlled conditions }\end{array}$ & $\begin{array}{l}\text { Reference photos from } \\
\text { the field }\end{array}$ \\
\hline $\begin{array}{l}\text { Robinia } \\
\quad \text { pseudoacacia }\end{array}$ & Black locust & 1,3 & $\begin{array}{l}\text { Very fine light brown interveinal stippling, } \\
\text { finally also with dark purple stippling. Stippling } \\
\text { can also be associated with leaf chlorosis and } \\
\text { accelerated senescence. }\end{array}$ & $\mathrm{O}$ & $\begin{array}{l}\text { Feng et al. } \\
\text { (unpublished) }\end{array}$ & $\begin{array}{l}\text { Innes et al., 2001; Sanz } \\
\text { et al., 2001; Sanz and } \\
\text { Calatayud, } 2013\end{array}$ \\
\hline Sambucus williamsii & $\begin{array}{l}\text { North China red } \\
\text { elder }\end{array}$ & 3 & $\begin{array}{l}\text { Dark brown stippling on interveinal parts of } \\
\text { older leaves. Stippling evolves to form very } \\
\text { distinctive brown necrotic areas, sometimes } \\
\text { with associated white flecking. Chlorosis is } \\
\text { frequently observed together with stippling. }\end{array}$ & $\mathrm{N}, \mathrm{O}$ & $\begin{array}{l}\text { Other Sambus species: } \\
\text { Sanz and Calatayud, } \\
2013\end{array}$ & $\begin{array}{l}\text { Other Sambucus } \\
\text { species: Innes et al., } \\
2001 \text {; Sanz et al., 2001; } \\
\text { Sanz and Calatayud, } \\
2013\end{array}$ \\
\hline $\begin{array}{l}\text { Vigna unguiculata } \\
\text { subsp. } \\
\text { sesquipedalis }\end{array}$ & $\begin{array}{l}\text { Chinese long bean, } \\
\text { cowpea }\end{array}$ & $1,2,4,7$ & $\begin{array}{l}\text { Distinctive purple-brown or dark purple } \\
\text { stippling that can cover a large portion of the } \\
\text { interveinal areas of leaves. Sometimes with } \\
\text { associated chlorosis. Severely affected leaves } \\
\text { finally becoming dry. }\end{array}$ & C & Umponstira et al., 2006 & This paper \\
\hline $\begin{array}{l}\text { Vitex negundo var. } \\
\text { heterophylla }\end{array}$ & $\begin{array}{l}\text { Five-leaved chaste } \\
\text { tree }\end{array}$ & 1 & $\begin{array}{l}\text { Reddish purple interveinal stippling affecting } \\
\text { older leaves }\end{array}$ & $\mathrm{O}$ & & This paper \\
\hline Vitis vinifera & Grape vine & 2 & $\begin{array}{l}\text { Brown and purple-brown interveinal stippling } \\
\text { on the adaxial side of older leaves }\end{array}$ & C & Shertz et al., 1980 & $\begin{array}{l}\text { Innes et al., 2001; Sanz } \\
\text { and Calatayud, } 2013\end{array}$ \\
\hline
\end{tabular}

Among crops, it is noteworthy the fact that different types of beans belonging to the genera Canavalia, Vigna, and Phaseolus showed distinctive and severe ozone symptoms in most of the places examined (Table 1; Fig. 3.7 and 3.8). Sensitivity of beans of the genus Phaseolus to ozone is well known and indeed Phaseolus vulgaris has been widely used in bio-indication studies as those regularly carried out in the framework of The International Cooperative Programme on Effects of Air Pollution on Natural Vegetation and Crops, ICP-Vegetation (e.g., Harmens et al., 2010). In Europe, visible injury in Phaseolus vulgaris has been widely reported (Hayes et al., 2007). However, little was known until now about the ozone sensitivity of Canavalia and Vigna species and varieties. These species have a strong potential to be used as ozone bio-indicators in China given that they are sensitive and commonly planted. Symptoms in courgette and gourd plants were also distinctive (Fig. 3.9 and 3.10). In watermelon, the observed necrotic areas and white flecking in the leaves (Fig. 3.11) were in agreement with those confirmed experimentally by Gimeno et al. (1989) in this species. Grapevine symptoms (Fig. 3.12) are similar to those reported by Innes et al. (2001) from Southern Switzerland. Okra plant, peanut and hop also showed symptoms occasionally.

The best bio-indicator tree for Beijing area is Ailanthus altissima (Fig. 3.1), because it is a common species throughout all the area

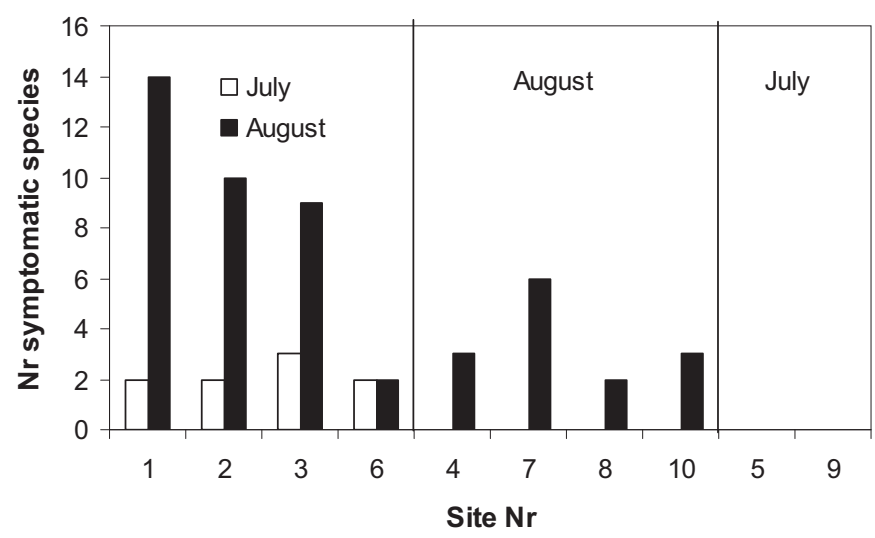

Fig. 2. Investigated areas for ozone-induced visible injury in Beijing. In sites 1, 2, 3 and 6, two surveys were carried out (July and August). Sites 4, 7, 8 and 10 were visited only on August, and 5 and 9 only on July. and ozone symptoms are very well characterized. Furthermore, it is a very sensitive species (Feng et al., unpublished) and symptoms already appear at the end of July. Its high sensitivity can be attributed to its leaf structure, with low leaf density and large intercellular spaces (Gravano et al., 2003). These authors observed that injury started at an AOT40 of only $5000 \mathrm{ppb}$ h. In eastern USA, it performs comparably to the other well-known bioindicator plants (Davies and Orendovici, 2006). Ozone symptoms in Chinese and Korean ashes were less evident than those regularly observed in Southern Europe in the European ash (Fraxinus excelsior), one of the best native bio-indicators in Europe (compare Fig. 3.3 with Innes et al., 2001). Several pine trees showed chlorotic mottling, sometimes associated with accelerated senescence, consistent with that produced by ozone (Fig. 3.4) (Miller et al., 1963; Skelly et al., 1987; Sanz et al., 2001). Pines have the potential to be used more extensively as ozone bio-indicators, although special care has to be taken as insects and mites can produce misleading symptoms (Skelly et al., 1987; Sanz et al., 2001). Koelreuteria paniculata is commonly planted but not frequently symptomatic (Fig. S1.8), and Ampelopsis humulifolia (Fig. 3.2) and Sambucus williamsii exhibited clear symptoms (Fig. S1.10)) under ambient ozone levels but their restricted distribution limits their possible use in extensive studies.

Among ornamental plants (Fig. 3.6), the rose of Sharon is a commonly planted species with clear ozone symptoms. Its use as ozone bio-indicator has been previously suggested by Paoletti et al. (2009a). On the other hand, the Japanese morning glory (Fig. S1.7) has been proposed as a possible bio-indicator for tropical areas (Ferreira et al., 2012; Moraes et al., 2014), and the black locust (Robinia pseudoacacia, Fig. 3.5) is a well-known ozone bio-indicator in the USA (Innes et al., 2001). These three species should be taken into accounted in more intensive and extensive surveys.

In summary, the present study clearly documents for the first time that phytotoxic ozone effects on vegetation and crops are widespread in Beijing area, and suitable species for broader biomonitoring surveys in temperate China have been identified. In the short term, this information will be used as a starting point for a broader field study involving several provinces of North China Plain. As the presence of foliar symptoms does not necessarily imply that there are significant effects on growth, yield or reproduction, this study has also identified sensitive species of interest to be further investigated under controlled conditions or using ozoneprotectants such as ethylenediurea (EDU) (Feng et al., 2010; Manning et al., 2011). Biomonitoring studies provide biologically 

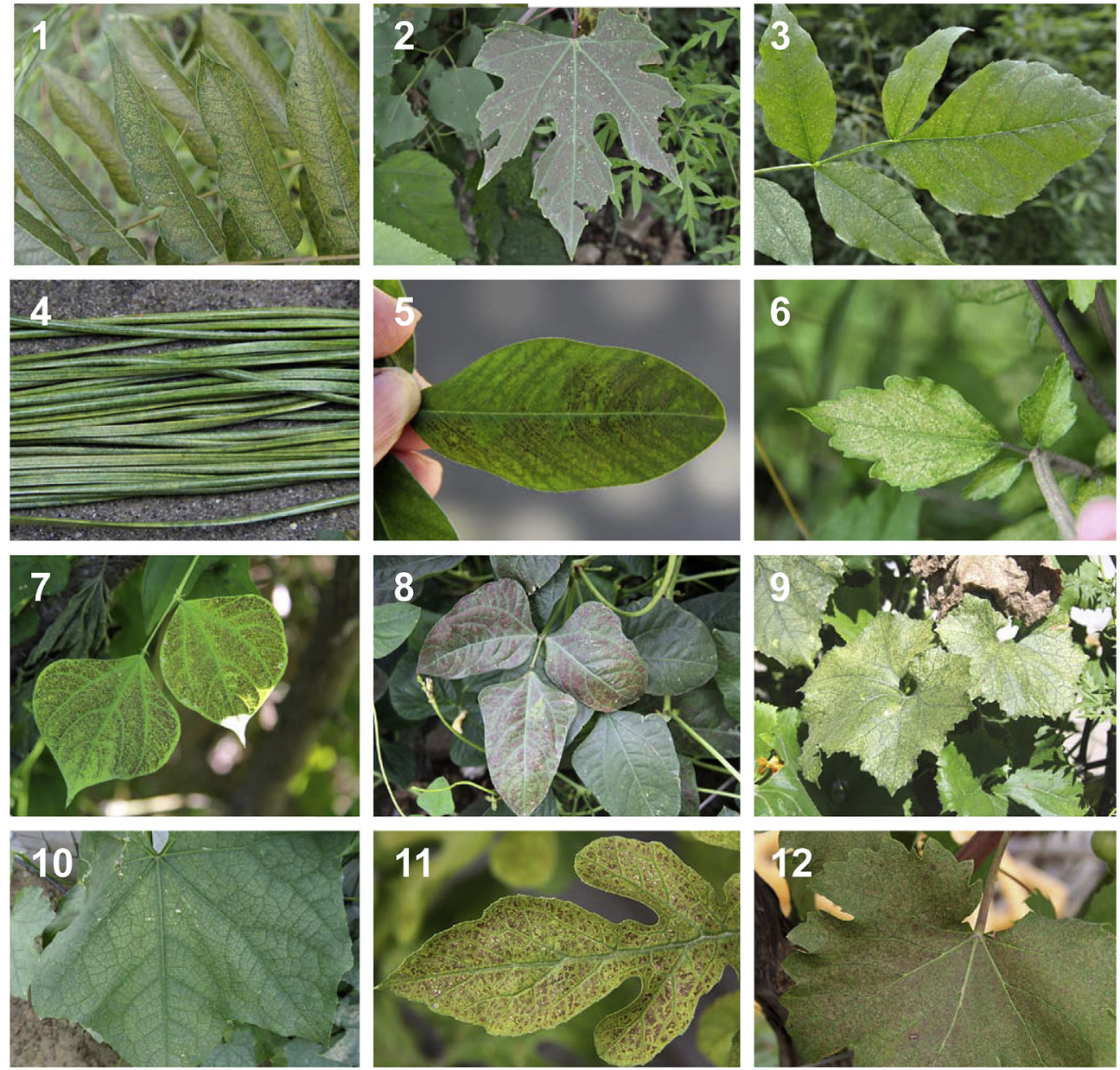

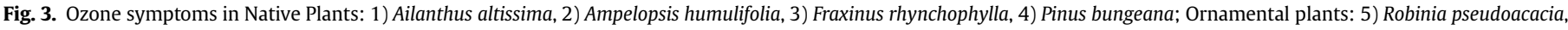
6) Hibiscus syriacus; Crops: 7) Canavalia gladiata, 8) Vigna unguiculata var. heterophylla, 9) Benincasa pruriens, 10) Luffa cylindrica, 11) Citrullus lanatus, and 12) Vitis vinifera.

relevant information that is complementary of ambient ozone monitoring systems, and help to raise ozone policy issues related to vegetation protection. The results of this study are also expected to contribute to the environmental awareness to the general public: bio-indicator plants have a strong potential to be used in communicating aspects of environmental pollution to the broad public given that visible injury symptoms are more perceptible and comprehensible for laymen than air pollution concentrations (Klumpp et al., 2002). Measures have to be taken to protect both the population and the plants from this pollutant.

\section{Acknowledgements}

This study has been funded by the Hundred Talents Program, Chinese Academy of Sciences and project AMIS (Fate and Impact of Atmospheric Pollutants, PIRSES-GA-2011-295132). It is also supported by the Chinese Academy of Sciences Visiting Professorships for Senior International Scientists (Grant Number: 2013T2Z0009). Fundación CEAM acknowledges the support of project GRACCIE (CONSOLIDER 2010, CSD2007-0067).

\section{Appendix A. Supplementary data}

Supplementary data related to this article can be found at http:// dx.doi.org/10.1016/j.envpol.2014.06.004.

\section{References}

Ainsworth, E.A., Yendrek, C.R., Sitch, S., Collins, W.J., Emberson, L.D., 2013. The ef fects of tropospheric ozone on net primary productivity and implications for climate change. Annu. Rev. Plant Biol. 63, 637-661.

Bergweiler, C., Carreras, H., Wannaz, E., Rodriguez, J., Toselli, B., Olcese, L., Pignata, M.L., 2008. Field surveys for potential ozone bioindicator plant species in Argentina. Environ. Monit. Assess. 138, 305-312.

Bulbovas, P., Sant'Anna II, S.M.R., Moraes, R.M., Lima, E.S., Pina, J.M., Esposito, M.P. Ferreira, M.L., Spielmann, A.A., Sollito, C.M., Rinnert, C.H., Peralta, D.F., Cardoso, J.S., Carminitti, L., Canêz, L.S., Reix, M.M.S., Benatti, M.N., Souzal, S.R., Domingos, M., 2008. Avaliação da sensibilidade de plantas jovens de quiabo (Abelmoschus esculentus (L.) Moench. - Malvaceae) ao ozônio. Hoehnea 35 (3), 359-366.

Bussotti, F., 2008. Functional leaf traits, plant communities and acclimation processes in relation to oxidative stress in trees: a critical overview. Glob. Change Biol. 14, 2727-2739.

Bussotti, F., Schaub, M., Cozzi, A., Kräuchi, N., Ferretti, M., Novak, K., Skelly, J.M., 2003. Assessment of ozone visible symptoms in the field: perspectives of quality control. Environ. Pollut. 125, 81-89.

Calatayud, V., Cerveró, J., Calvo, E., García-Breijo, J.F., Reig-Armiñana, J., Sanz, M.J., 2011. Responses of evergreen and deciduous Quercus species to enhanced ozone levels. Environ. Pollut. 159, 55-63.

Campbell, S.J., Wanek, R., Coulston, J.W., 2007. Ozone Injury in West Coast Forests: 6 Years of Monitoring. Gen. Tech. Rep. PNW-GTR-722. U.S. Department of Agriculture, Forest Service, Pacific Northwest Research Station, Portland, OR, 53 pp.

Convention, L.R.T.A.P., 2010. Manual on Methodologies and Criteria for Modelling and Mapping Critical Loads and Levels and Air Pollution Effects, Risks and Trends, 2010 Revision. Available from. : www.icpmapping.org.

Coulston, J.W., Smith, G.C., Smith, W.D., 2003. Regional assessment of ozone sensitive tree species using bioindicator plants. Environ. Monit. Assess. 83 (2), 113-127.

Davies, D.D., Oerndovici, T. 2006. Incidence of ozone symptoms on vegetation within a National Wildlife Refuge in New Jersey, USA. Environ. Pollut. 143, 555-564.

de Vries, W., Reinds, G.J., Posh, M., Sanz, M.J., Krause, G., Calatayud, V., Renaud, J.P., Dupoucy, H., Sterba, H., Vel, E.M., Dobbertin, M., Gundersen, P., Voogd, J.C.H., 
2003. Intensive Monitoring of Forest Ecosystems in Europe, 2003 Technical Report. EC-UN/ECE, Brussels, Geneva (ISSN 1020-6078), 163 pp.

Di Baccio, D., Castagna, A., Paoletti, E., Sebastiani, L., Ranieri, A., 2008. Could the differences in $\mathrm{O}_{3}$ sensitivity between two poplar clones be related to a difference in antioxidant defense and secondary metabolic response to $\mathrm{O}_{3}$ influx? Tree Physiol. 28, 1761-1772.

Ding, A.J., Wang, T., Thouret, V., Cammas, J.P., Nedéléc, P., 2008. Tropospheric ozone climatology over Beijing: analysis of aircraft data from the MOZAIC program. Atmos. Chem. Phys. 8, 1-13.

Feng, Z., Wang, S., Szantoi, Z., Chen, S., Wang, X., 2010. Protection of plants from ambient ozone by applications of ethylenediurea (EDU): a meta-analytic review. Environ. Pollut. 158, 3236-3242.

Ferreira, M.L., Esposito, J.B.N., de Souza, S.R., Domingos, M., 2012. Critical analysis of the potential of Ipomoea nil 'Scarlet O'Hara' for ozone biomonitoring in the sub-tropics. J. Environ. Monit. 14, 1959-1967.

Fumagalli, I., Gimeno, B.S., Velissariou, D., De Temmerman, L., Mills, G., 2001. Evidence of ozone-induced adverse effects on crops in the Mediterranean region. Atmos. Environ. 35 (14), 2583-2587.

Gimeno, B.S., Selleras, J.M., Bermejo, V., Ochoa, M.J., Tarruel, A., 1989. Efectos del ozono sobre plantas de Sandía en el Delta del Ebro: sintomatología (II). Phytoma Esp. 12, 19-28.

Gravano, E., Giulietti, V., Desotgiu, R., Bussotti, F., Grossoni, P., Gerosa, G., Tani, C. 2003. Foliar response of an Ailanthus altissima clone in two sites with different levels of ozone-pollution. Environ. Pollut. 121, 137-146.

Harmens, H., Mills, G., Hayes, F., Norris, D., the participants of the ICP Vegetation, 2010. Air Pollution and Vegetation. ICP Vegetation Annual Report 2009/2010, 40 pp.

Hayes, F., Mills, G., Harmens, H., Norris, D., 2007. Evidence of Widespread Ozone Damage to Vegetation in Europe (1990-2006). Programme Coordination Centre for the ICP Vegetation, Centre for Ecology and Hydrology, Bangor, UK., ISBN 978-0-9557672-1-0

Innes, J.L., Skelly, J.M., Schaub, M., 2001. Ozone and broadleaved species. A guide to the identification of ozone-induced foliar injury. Ozon, Laubholz- und Krautpflanzen. Ein Führer zum Bestimmen von Ozonsymptomen. Birmensdorf, Eidgenössische Forschungsanstalt WSL, Bern, Stuttgart, Wien. Haupt. 136 pp.

Intergovernmental Panel on Climate Change (IPCC), 2013. Fifth Assessment Report. http://www.ipcc.ch/report/ar5/index.shtml.

Klumpp, A., Ansel, W., Klumpp, G., Belluzzo, N., Calatayud, V., Chaplin, N., Garrec, J.P., Gutsche, H.-J., Hayes, M., Hentze, H.-W., Kambezidis, H., Laurent, O. Peñuelas, J., Rasmussen, S., Ribas, A., Ro-Poulsen, H., Rossi, S., Sanz, M.J., Shang, H. Sifakis, N., Vergne, P., 2002. EuroBionet: a Pan-European biomonitoring network for urban air. Environ. Sci. Pollut. Res. 9 (3), 199-203.

Krupa, S., McGrath, M.T., Andersen, C.P., Booker, F., Burkey, K.O., Chappelka, A.H. Chevone, B.I., Pell, E.J., Zilinskas, B.A., 2000. Ambient ozone and plant health. Plant Dis. 85, 4-12.

Manning, W.J., Godzik, B., 2004. Bioindicator plants for ambient ozone in Centra and Eastern Europe. Environ. Pollut. 130 (1), 33-39.

Manning, W.J., Paoletti, E., Sandermann Jr., H., Ernst, D., 2011. Ethylenediurea (EDU): a research tool for assessment and verification of the effects of ground level ozone on plants under natural conditions. Environ. Pollut. 159, 3283-3293.

Miller, P.R., Parmeter, J.R., Taylor, O.C., Cardiff, E.A., 1963. Ozone injury to the foliage of Pinus ponderosa. Phytopathology 53, 1072-1076.

Moraes, R., Meirelles, S.T., Silva, S.F., Silva, D.T., de Assis, P.I.L.S., Viola, S.R.A.S., 2014 Leaf Injury and Gas Exchange in Ipomoea Nil Cv. Scarlett O'Hara, an Ozone Bioindicator Species, vol. 5. Atmospheric Pollution Research, Sao Paulo, Brazil, pp. 8-12.
Paoletti, E., Ferrara, A.M., Calatayud, V., Cerveró, J., Sanz, M.J., 2009a. Deciduous shrubs for ozone bioindication: Hibiscus syriacus as an example. Environ. Pollut. 157, 865-870.

Paoletti, E., Contran, N., Bernasconi, P., Günthardt-Goerg, M.S., Vollenweider, P., 2009b. Structural and physiological responses to ozone in Manna ash (Fraxinus ornus L.) leaves of seedlings and mature trees under controlled and ambient conditions. Sci. Total Environ. 407, 1631-1643.

Royal Society, 2008. Ground-level Ozone in the 21st Century: Future Trends, Impacts and Policy Implications. Science Policy Report 15/08. The Royal Society, London, UK.

Sanz, M.J., Calatayud, V., 2013. Ozone Injury in European Forest Species (accessed 04.12.13). http://www.ozoneinjury.org/.

Sanz, M.J., Calvo, E., 2013. Ozone Injury in Crops (accessed 04.12.13) http:// www.ozoneinjury.org/crops/.

Sanz, M.J., Sánchez, G., Calatayud, V., Minaya, M., Cerveró, J., 2001. La contaminación atmosférica en los bosques: Guía para la identificación de daños visibles causados por Ozono. Organismo Autónomo de Parques Nacionales, Madrid, 163 pp.

Schaub, M., Calatayud, V., 2013. Assessment of visible foliar injury induced by ozone. In: Ferretti, M., Fisher, R. (Eds.), Forest Monitoring, Methods for Terrestrial Investigations in Europe with an Overview of North America and Asia, Developments in Environmental Science 12. Elsevier, Oxford (UK), pp. 205-221.

Schaub, M., Calatayud, V., Ferreti, M., Brunialti, G., Lövblad, G., Krause, G., Sanz, M.J., 2010. Assessment of Ozone Injury. Manual on Methods and Criteria for Harmonized Sampling, Assessment, Monitoring and Analysis of the Effects of Air Pollution on Forests. 1-22. UNECE ICP Forests Programme Co-ordinating Centre, Hamburg. Available at: http://icp-forests.net/.

Shertz, R.D., Kender, W.J., Musselman, R.C., 1980. Effectst of ozone and sulfur dioxide on grapevines. Sci. Hortic. 13, 37-45.

Skelly, J.M., Davis, D.D., Merril, W., Cameron, E.A., 1987. In: Brown, H.D., Drummond, D.B., Dochinger, L.S. (Eds.), Diagnosing Injury to Eastern Forest Trees. PennState College of Agriculture, University Park, 122 pp.

Skelly, J.M., Innes, J.L., Savage, J.E., Snyder, K.R., Vanderheyden, D., Zhang, J., Sanz, M.J., 1999. Observation and confirmation of foliar ozone symptoms of native plant species of Switzerland and southern Spain. Water Air Soil Pollut. $116(1-2), 227-234$

Umponstira, C., Pimpa, W., Nanegrungsun, S., 2006. Physiological and biochemical responses of cowpea (Vigna unguiculata (L.) Walp) to ozone. Songklanakarin J. Sci. Technol. 28 (4), 861-869.

Vollenweider, P., Ottiger, M., Günthardt-Goerg, M.S., 2003. Validation of leaf ozone symptoms in natural vegetation using microscopical methods. Environ. Pollut. 124, 101-118.

Vollenweider, P., Fenn, M.E., Menard, T., Gunthardt-Goerg, M., Bytnerowicz, A., 2013. Structural injury underlying mottling in ponderosa pine needles exposed to ambient ozone concentrations in the San Bernardino Mountains near Los Angeles. California. Trees 27, 895-911.

Wan, W.X., Xia, Y.J., Zhang, H.X., Wang, J., Wang, X.K., 2013. The ambient ozone pollution and foliar injury of the sensitive woody plants in Beijing exurban region. Acta Ecol. Sin. 33 (4), 1098-1105 (in Chinese).

Witting, V.E., Ainsworth, E.A., Naidu, S.L., Karnosky, D.F., Long, S.P., 2009. Quantifying the impact of current and future tropospheric ozone on tree biomass, growth, physiology and biochemistry: a quantitative meta-analysis. Glob. Change Biol. 15, 396-424.

Zhang, W.W., Feng, Z.Z., Wang, X.K., Niu, J.F., 2012. Responses of native broadleaved woody species to elevated ozone in subtropical China. Environ. Pollut. 163, 149-157. 